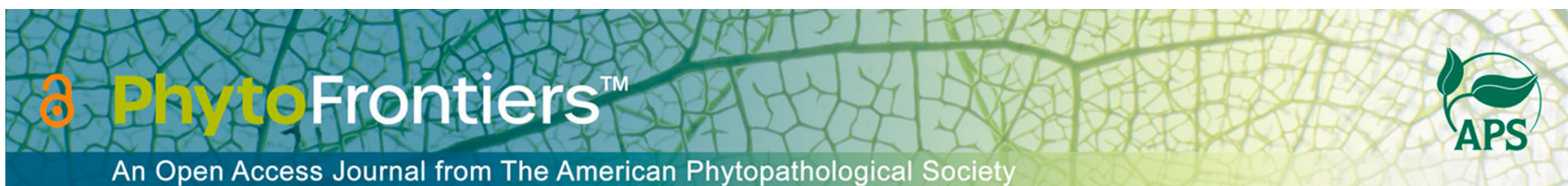

\title{
Research
}

\section{Adoption of Best Management Practices for Grapevine Leafroll and Red Blotch Diseases: A Survey of West Coast Growers}

\author{
Malcolm B. Hobbs ${ }^{1}$ (D) | Selena M. Vengco ${ }^{1}$ | Stephanie L. Bolton ${ }^{2}$ | Larry J. Bettiga ${ }^{3}$ | \\ Michelle M. Moyer ${ }^{4} \mid$ Monica L. Cooper ${ }^{1,+}$ |
}

1 University of California Cooperative Extension, Napa, CA 94559

${ }^{2}$ Lodi Winegrape Commission, Lodi, CA 95242

${ }^{3}$ University of California Cooperative Extension, Salinas, CA 93901

${ }^{4}$ Washington State University Irrigated Agriculture Research and Extension Center, Prosser, WA 99350

† Corresponding author: M. L. Cooper; mlycooper@ucanr.edu

Accepted for publication 24 November 2021.

\section{Funding}

Funding was provided by the California Department of Food and Agriculture, Pierce's disease and glassy-winged sharpshooter program, CDFA Agreement Number 19-0271-000-SA

The author(s) declare no conflict of interest.

\begin{abstract}
Grapevine leafroll disease (GLD) and red blotch disease (RBD) threaten the sustainability of the U.S. wine grape industry. To understand the factors influencing the adoption of disease management practices, we surveyed wine grape industry professionals in California, Oregon, and Washington $(n=154)$. Economic factors were the fundamental cost of implementing management practices and the ability to sell products from diseased vines (salability). Respondents who encountered reduced salability were more likely to adopt virus testing, replace infected vines, and view these practices as economically favorable. Salability was a strong driver for adoption among Californian respondents but less so in Washington, where wineries appeared more willing to accept infected products. Respondents who had acquired technical knowledge of disease ecology were more likely to adopt management practices and to perceive them as economical. Conversely, when there was a lack of knowledge of GLD ecology, notably that mealybugs transmit the pathogen, adoption was reduced, and practices were considered less economical. Factors affecting adoption were broadly generalizable across diseases. However, knowledge of GLD ecology was more strongly associated with adoption, likely reflecting the remaining knowledge gaps in RBD related to vector ecology and field spread. An emphasis on grower knowledge acquisition and the development of economical disease management practices can improve adoption of best management practices for viral diseases of grapevine.
\end{abstract}

Keywords: adoption of best management practices, disease management, leafroll disease, red blotch disease

Pest and disease pressure poses a threat to the sustainability of agriculture. Producers often manage these risks by relying on standard practice rather than adopting new technologies or tools (Lefebvre et al. 2015), suggesting that there are technical, social, and economic factors that must be overcome to increase producers' capability to adopt new practices. Applied research and educational programs that address these factors seek to 
narrow the research-to-innovation divide, support producers in risk management, and encourage the adoption of new evidencebased practices (Barzman et al. 2015; Buurma and van der Velden 2017; Farrar et al. 2016).

Typically, the supply of technical knowledge was perceived as the primary limiting factor for the adoption of practices, meaning practices are not adopted either because the knowledge has not been created or producers have not acquired the knowledge. However, social factors related to how knowledge is delivered and interpreted by end users have emerged as important considerations (Buurma and van der Velden 2017). Economic factors such as increased quantity and quality of products, improved growth, reduced crop losses, and increased access to markets or new opportunities to sell products also influence adoption (Buurma and van der Velden 2017; Lefebvre et al. 2015). Conversely, high implementation costs reduce the adoption of beneficial practices, as seen in dairy farming (Bechini et al. 2020), water management (Yang and Sharp 2017), and grapevine trunk diseases (Kaplan et al. 2016). Often, the integrated approach to pest and disease management is information- and knowledge-intensive, requiring an initial investment in training resources (Lefebvre et al. 2015). The benefits of adopting sustainable practices, however, can extend beyond the individual producer to farmworkers, consumers, and natural ecosystems. Because of the potential effects on outside agents, public policies can be implemented to encourage the adoption of sustainable practices and integrated management programs (Lefebvre et al. 2015).

Grapevine leafroll disease (GLD) and grapevine red blotch disease (RBD) are among the most consequential viral diseases of grapevines. Financial losses result from reduced vegetative growth, fruit quality, and yields (Atallah et al. 2012; BlancoUlate et al. 2017; Bowen et al. 2020; Cieniewicz et al 2018; Martínez-Lüscher 2019; Naidu et al. 2014; Ricketts et al. 2015; Sudarshana et al. 2015). Grapevine leafroll-associated virus 3 (GLRaV-3) is the most widely occurring pathogen associated with GLD (Almeida et al. 2013; Maree et al. 2013) and Grapevine red blotch virus is the causal agent of RBD (Yepes 2018). Both pathogens can be introduced to a vineyard via infected plant material. Vine-to-vine transmission of GLRaV-3 occurs via insect vectors, including mealybugs and soft scale insects (Almeida et al. 2013; Herrbach et al. 2017). Grape mealybug (Pseudococcus maritimus) is the most common vector in North America, whereas the invasive vine mealybug (Planococcus ficus) is particularly problematic in California (Daane et al. 2012). Field spread of RBD has been observed (Cieniewicz et al. 2017, 2019), and studies confirm that the threecornered alfalfa hopper (Spissistilus festinus) is a vector under controlled conditions (Bahder et al. 2016; Flasco et al. 2021).

Epidemiological studies of GLD have resulted in a series of evidence-based management practices aimed at minimizing the introduction of GLRaV-3 to new areas and reducing local spread (Almeida et al. 2013; Arnold et al. 2017; Bell et al. 2018; Charles et al. 2009; Poojari et al. 2017; Pietersen et al. 2013; Sokolsky et al. 2013). These practices include clean plant programs to maintain virus-tested nursery stock, diagnostic assays of established vines, removal and replacement of infected vines, and vector management. Although epidemiological studies for RBD have not yet coalesced into actionable guidelines (Bahder et al. 2016; Bowen et al. 2020; Cieniewicz et al. 2018; Preto et al. 2018), mitigation efforts focus on exclusion by planting certified material and removing infected vines to reduce spread (Ricketts et al. 2017).

The current study reports a survey of wine grape industry professionals in California and the Pacific Northwest (Oregon and Washington State) that quantified adoption and perceptions of management practices for GLD and RBD, with a focus on economic considerations and technical knowledge. The primary aim was to identify probable factors that act as barriers to the adoption of best management practices and, conversely, what might drive adoption to overcome those barriers. As insect-vectored viruses causing incurable diseases of grapevine, GLD and RBD share key similarities; however, disease ecology is more fully understood for GLD, whereas important knowledge gaps remain for RBD. The secondary aim was therefore to compare the diseases to gain insight into how factors affecting adoption might differ between an established and more recently emerged disease. Ultimately, an improved understanding of factors influencing adoption of management practices will contribute to efforts to narrow the research-to-innovation divide for incurable viral diseases of perennial crops.

\section{MATERIALS AND METHODS}

\section{Survey questions}

Using a quantitative survey, we collected demographic information and assessed three areas presumed to be consequential to GLD and RBD management: (i) adoption of disease management practices, (ii) perceived costs related to disease management, and (iii) technical knowledge of disease ecology (Box 1).

\section{Sample}

From April 2019 through December 2020, the survey was delivered to audiences at regional meetings using polling software (Turning Technologies, Youngstown, OH, U.S.A.) or online using a survey tool (Qualtrics, Provo, UT, U.S.A.). Responses were collected from 154 grape industry professionals in California $(n=134)$ and the Pacific Northwest $(n=20)$. Respondents held varying roles within the wine grape industry, such as in senior management (director of viticulture, vineyard manager, owner), winemaking, technical farming positions (viticulturist, consultant), and technical assistance (intern, field scout). Most respondents grew a combination of red and white Vitis vinifera cultivars $(63.6 \%)$, and the remainder were dedicated red $(29.2 \%)$ or white $(0.6 \%)$ grape growers. The most common cultivars were Cabernet Sauvignon (75.5\%), Chardonnay (54.9\%), and Pinot noir $(35.8 \%)$. The presence of GLD and RBD in vineyards was reported by $140(91 \%)$ and $135(88 \%)$ respondents, respectively. Five respondents (3\%) reported no GLD, and eight (5\%) reported no RBD; the remainder (6 to 7\%) did not answer the question. Respondents from California worked in 13 grape pricing districts, with the largest groupings from District 4 (Napa; 47.8\%), District 3 (Sonoma/Marin; 7.5\%), District 7 (Monterey/San Benito; $6.7 \%$ ), and District 5 (Solano; $3 \%$ ), and $12.7 \%$ working across multiple districts. Respondents from Washington worked across 13 American Viticultural Areas; of those who worked in a single American Viticultural Area, the most common were Yakima Valley $(68 \%)$ and Horse Heaven Hills (47\%). A single respondent worked in Oregon. Other salient demographics are summarized in Table 1.

\section{Data reduction and analysis}

Descriptive data were produced for questions (Box 1) in areas 1 to 3 a related to practices adopted, perceived costs, and knowledge of disease ecology. These measures were compared with each other using cross-sectional analyses. The number of respondents that had adopted each practice (1) and perceived the cost of practices as "too expensive" (2a) were compared by responses on 
the knowledge statements (3), whether customers were willing to buy infected fruit or wine (2b), reported mealybugs (3b), and demographics (4). This allowed for comparison of how respondents differed by each measure in terms of practices adopted and perceived expense. Remaining comparisons were then made with the other measures: The amount of money respondents would be prepared to invest in control programs for each disease (2c), reported mealybugs (3b), and demographics were compared with all responses in sections 1 through 4 . In the interests of brevity, only significant relationships are reported below.

Respondents were assigned to "mealybug groups" based on whether they reported "no mealybugs" (No MB; $n=19$ ), vine/mainly vine mealybugs (VMB; $n=67$ ), or grape/mainly grape mealybugs (GMB; $n=52)$. Regional responses were tested between California and the Pacific Northwest only because, aside from Napa County, there were not enough responses from individual within-state growing areas to represent meaningful re-

\section{BOX 1}

Details of survey questions administered to grape industry professionals in California and the Pacific Northwest

1. Adoption of management practices

Checklist of practices adopted in the past 5 years for each disease:

- Virus testing of samples at nursery

- Virus testing from vineyard samples

- Mapping of visual symptoms

- Removal/replacement of infected vines

- Vector management

- Vegetation management (red blotch disease [RBD] only)

\section{Perceived costs of disease}

a. Checklist of practices considered "too expensive":

- Virus testing from samples at nursery

- Virus testing from vineyard samples

- Removal/replacement of infected vines

- Monitoring for mealybugs

- Controlling mealybugs

b. Customer(s) (winery) willing to buy or accept infected fruit or wine (yes/no)

c. Overall amount prepared to invest in control programs per acre: None; $<\$ 500 ; \$ 500$ to $\$ 1,000 ;>\$ 1,000$

3. Technical knowledge of disease ecology

a. The following are true/false about grapevine leafroll disease (GLD) or RBD:

- Reduces grape quantity (yield)

- Increases fruit quality

- There is a clear understanding of how disease spreads

- There is a clear understanding of how to control disease

- Infected blocks put neighboring blocks/vineyards at risk of infection

- Impacts the economic sustainability of the vineyard industry

- Mealybugs are vectors (GLD only)

b. Reported mealybugs: none; vine (or mainly) vine mealybugs; grape (or mainly) grape mealybugs

\section{Demographics}

Age, gender, job role, region, industry certifications, cultivars farmed, presence or absence of GLD and RBD gional groups. Reported sample sizes represent the numbers of respondents that answered the questions under consideration.

Data were analyzed using IBM SPSS 26 software. Relationships between measures were tested using chi square (Analyze $>$ Descriptive Statistics $>$ Crosstabs) for nominal data, utilizing Fisher's exact test when cells were less than 5. Weighted chi square using the SPSS Complex Samples Extension Crosstabs was used when it was known that groups were over/underrepresented (e.g., region). Likert scale data were analyzed using Kruskal-Wallis (Analyze > Nonparametric > Independent Samples) with post hoc Mann-Whitney U. Ranking data were tested for significance using Friedman's test (Analyze $>$ Nonparametric $>$ Related Samples) with post hoc Wilcoxon signed-rank tests. Holm's sequential Bonferroni procedure (Holm 1979) was applied to post hoc tests.

\section{RESULTS}

\section{Economic factors}

Overall, best management practices were adopted at rates ranging from $50.3 \%$ to $75.3 \%$ (Fig. 1) of the sampled population, aside from vegetation management, which was adopted by $29.7 \%$ of respondents. Most respondents had adopted at least one practice for GLD (89.6\%) and RBD (88.4\%), with a median of four out of five practices adopted for GLD and three out of six practices for RBD.

Visual symptom mapping. Respondents adopted visual symptom mapping at similar rates for GLD (52.1\%) and RBD $(50.3 \%)$. Adoption was not influenced by economic factors.

Removal and replacement of infected vines. The most widely adopted practice for GLD was the removal and replacement of infected vines (75.3\%), with adoption for RBD being slightly lower (63.4\%). Most respondents viewed removal and replacement as economical, but $25.4 \%$ of respondents viewed it as too expensive (Fig. 2). Respondents for whom salability of fruit, juice, or bulk wine was unaffected by the presence of diseased vines were more likely to report removal and replacement of infected vines as too expensive (Fig. 3).

Virus testing. Adoption of virus assays of vineyard samples was high for GLD (73.3\%) and RBD (71\%). Respondents who

\section{TABLE 1}

Demographics of survey respondents ${ }^{\mathrm{a}}$

\begin{tabular}{lclr}
\hline Job role & Count $(\%)$ & Age range & Count $(\%)$ \\
\hline Director of viticulture & $15(9.7 \%)$ & 20-29 years & $22(14.3 \%)$ \\
Vineyard manager & $29(18.8 \%)$ & 30-39 years & $46(29.9 \%)$ \\
Viticulturist & $43(27.9 \%)$ & $40-49$ years & $26(16.9 \%)$ \\
Winemaker & $9(5.8 \%)$ & $50-59$ years & $27(17.5 \%)$ \\
Vineyard owner & $10(6.5 \%)$ & $60+$ years & $20(13.6 \%)$ \\
Consultant/PCA & $24(15.6 \%)$ & & \\
Intern/field scout & $6(3.9 \%)$ & & \\
Other & $6(3.9 \%)$ & & Count $(\%)$ \\
\hline Industry certifications & Count $(\%)$ & Gender & $53(34.4 \%)$ \\
\hline CCA & $9(5.8 \%)$ & Female & $84(54.5 \%)$ \\
PCA & $50(32.5 \%)$ & Male & $5(3.2 \%)$ \\
PAL & $54(35.1 \%)$ & Other ID & \\
None & $34(22.1 \%)$ & & \\
\hline
\end{tabular}

Some values do not sum to study totals because some respondents did not provide responses. CCA = certified crop advisor; PCA = licensed pest control advisor; PAL = private applicator license and/or qualified applicator license/certificate (California only). Where respondents had more than one qualification, they were assigned based on their "highest" pest controlrelated qualification, with hierarchy indicated by the order in which they are listed. 
considered the practice too expensive reported lower adoption for both diseases (Figs. 4 and 5). Adoption of assays of nursery material was lower than for vineyard samples but was similar for each disease: GLD (65.1\%) and RBD (64.8\%), with a minority $(11.6 \%)$ considering the practice too expensive (Figs. 1 and 2).
For RBD, adoption of virus assays of nursery material was higher (25.5\%) when salability was a factor (Fig. 5).

Vector management. Adoption of vector management for GLD was high (73.3\%), despite $27.9 \%$ viewing mealybug control as too expensive and a minority $(5.4 \%)$ viewing mealybug

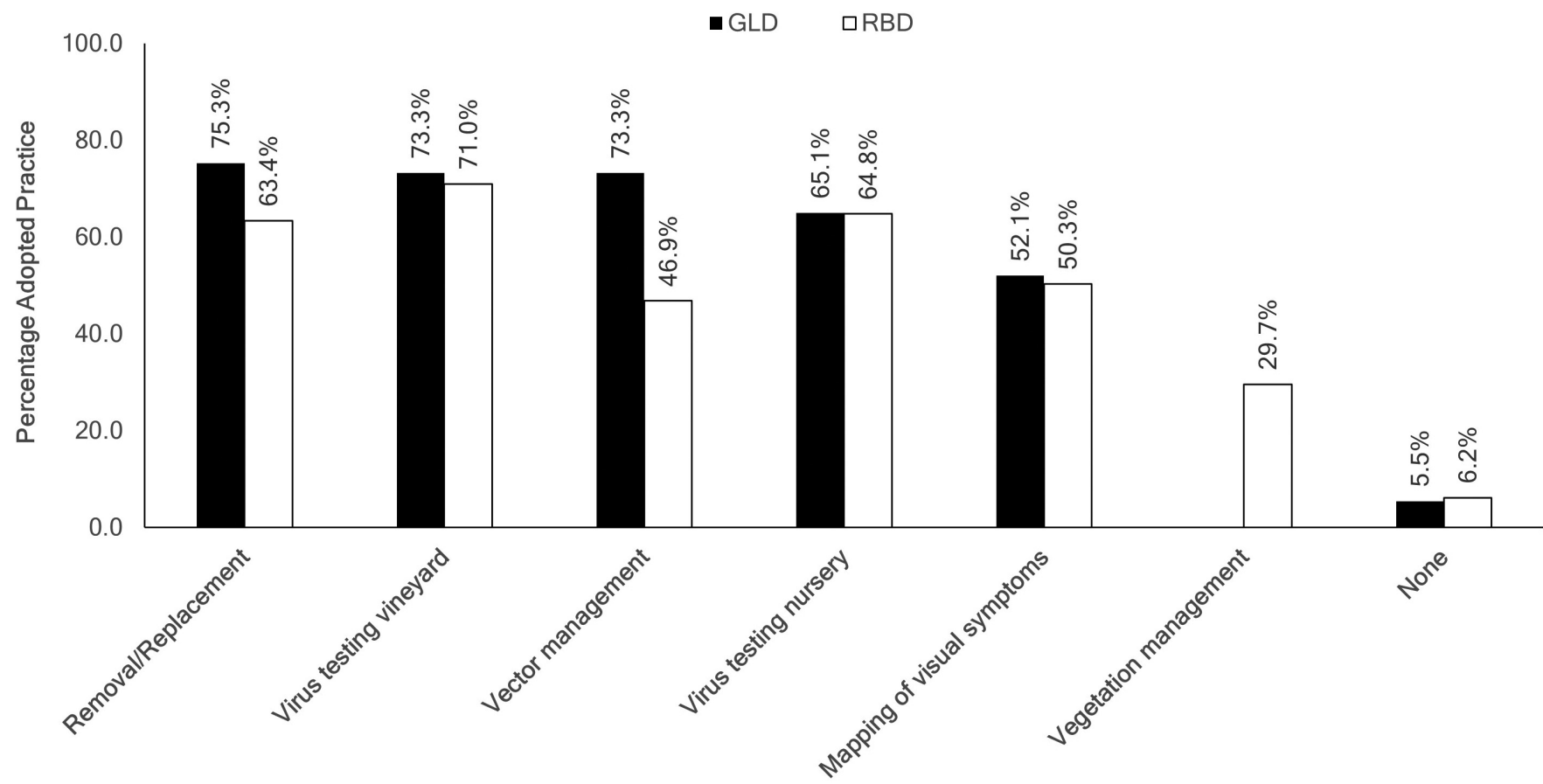

FIGURE 1

Survey participants' self-reported adoption of management practices in the past 5 years for grapevine leafroll disease (GLD) $(n=146)$ and grapevine red blotch disease (RBD) $(n=145)$. Adoption of vegetation management was measured for RBD only.

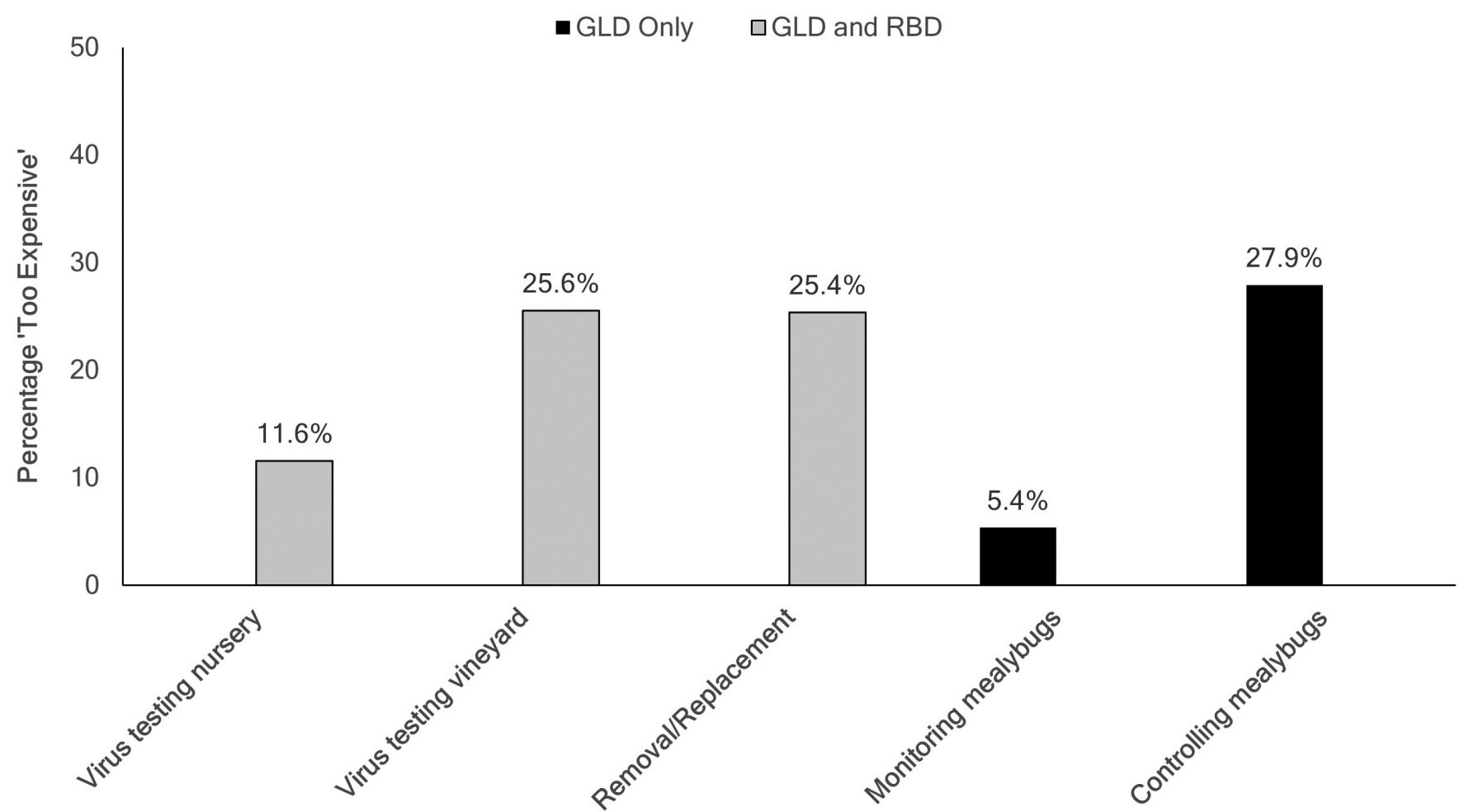

FIGURE 2

Percentage of respondents indicating a grapevine leafroll disease (GLD) or grapevine red blotch disease (RBD) mitigation practice was too expensive ( $n=56$ for mealybug monitoring; $n=126$ to 138 for other practices). 
monitoring as too expensive. When monitoring was viewed as too expensive, adoption of GLD vector management was reduced (Fig. 4). In comparison, adoption of vector management for RBD was considerably lower (46.9\%), with few respondents adopting vegetation management $(29.7 \%)$. Adoption was not influenced by economic factors.
Investment in control programs. Overwhelmingly, respondents were willing to invest in a disease management program (Fig. 6). Most were willing to pay under $\$ 500$ per acre for GLD $(55.7 \%)$ and RBD (51.1\%). Economic considerations were a factor in these responses. When salability was impacted, respondents were prepared to make larger investments in management (GLD,

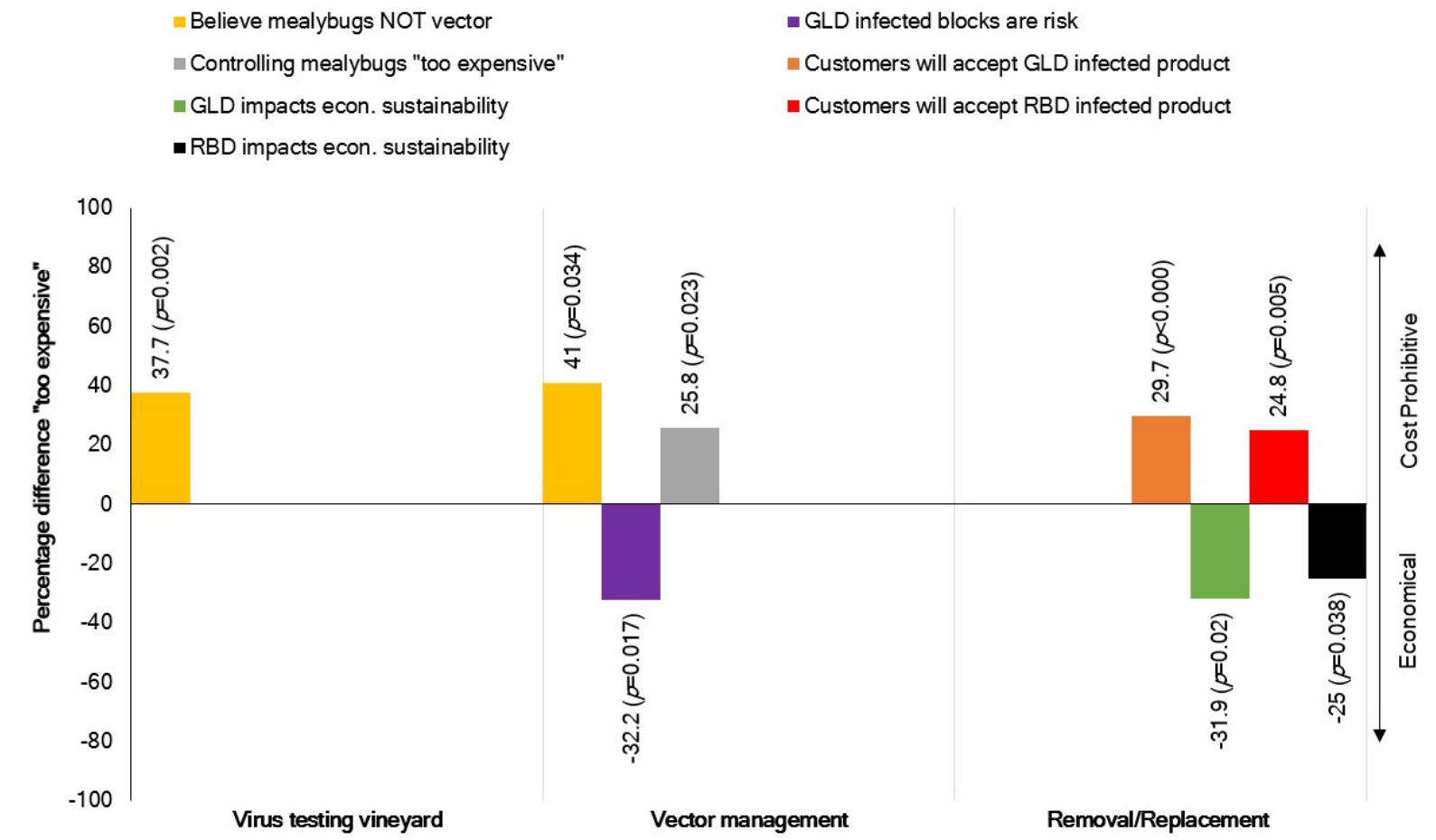

FIGURE 3

Difference in respondents who viewed grapevine leafroll disease (GLD) and grapevine red blotch disease (RBD) management practices-virus assays from vineyard samples, vector management, and removal/replacement of diseased vines-as "too expensive." Only significant comparisons are displayed.

$$
\begin{aligned}
& \text { - Practice "too expensive" } \quad \text { Report no mealybugs in vineyard } \quad \text { Believe mealybugs NOT vector } \\
& \text { Believe understanding of GLD control } \quad \text { Believe understanding of GLD spread } \quad \text { GLD impacts econ. sustainability }
\end{aligned}
$$

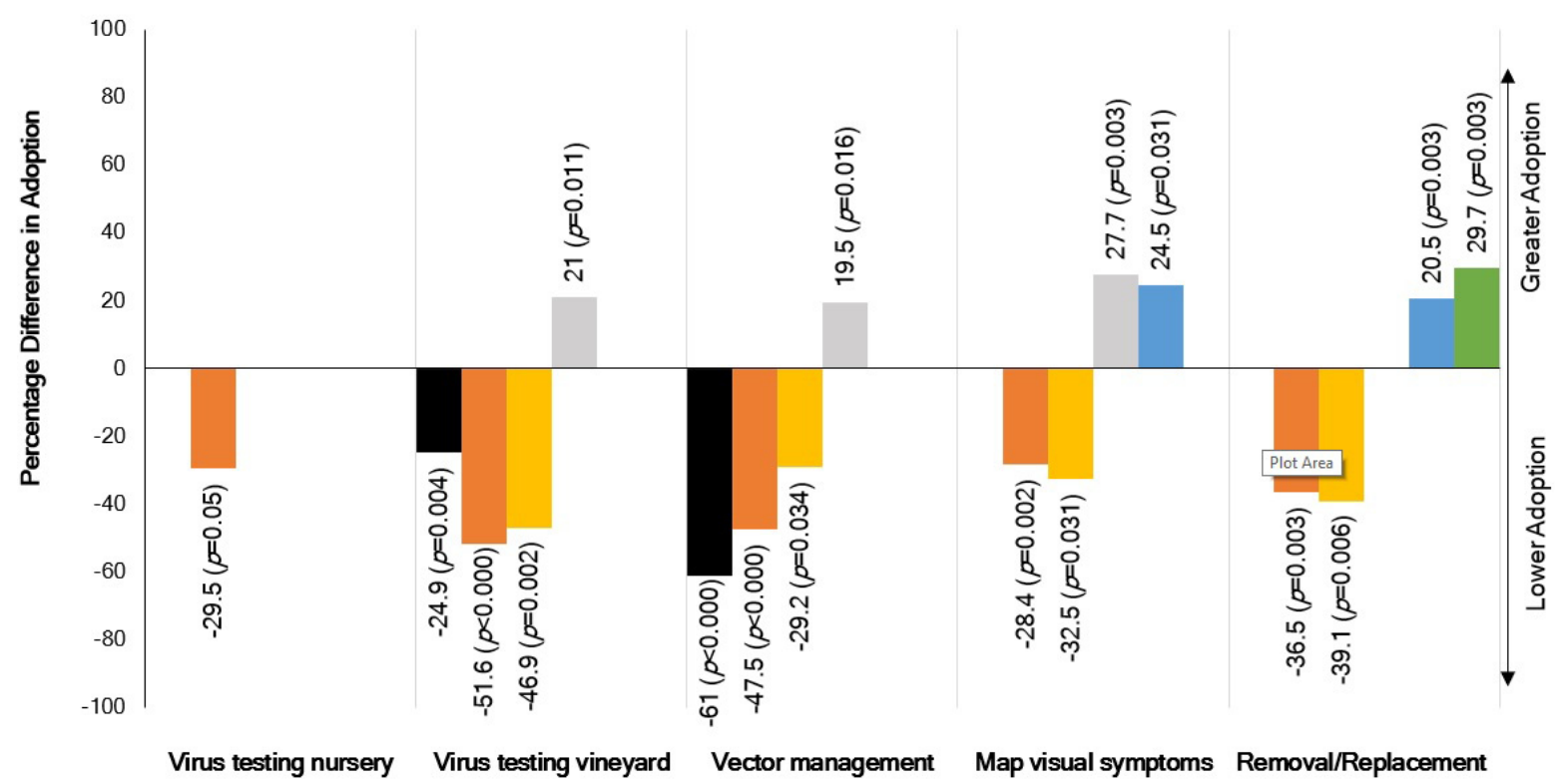

FIGURE 4

Difference in adoption among respondents of grapevine leafroll disease (GLD) management based on perceived costs and reported knowledge of disease ecology. Only significant comparisons are displayed. For vector management, "too expensive" refers to the cost of mealybug monitoring. 
$P=0.001$; RBD,$P<0.000$ ), with $51.2 \%$ and $54.3 \%$ of respondents prepared to invest more than $\$ 500$ per acre for GLD and $\mathrm{RBD}$, respectively. In comparison, when salability was not a factor, $76.6 \%$ and $82.4 \%$ of respondents were prepared to invest less than $\$ 500$ per acre for GLD and RBD, respectively.

\section{Technical knowledge of disease ecology}

Knowledge of disease ecology was a factor in the adoption of beneficial practices (Figs. 4 and 5). Most respondents correctly understood GLD epidemiology. For RBD, most respondents agreed that the disease has economic impacts and that infected blocks are a risk to neighboring vineyards (Fig. 7). However, there was less consensus that it reduces yields $(63.8 \%)$ and that there is a clear understanding of how the pathogen spreads $(51.1 \%)$ and how to control it $(48.2 \%)$. Very few respondents believed GLD $(6.3 \%)$ or RBD $(5 \%)$ increased fruit or wine quality.

GLRaV-3 transmission and impact on sustainability. Respondents who recognized that mealybugs are responsible for secondary spread of GLRaV-3 were more likely to both map visual symptoms and remove and replace infected vines (Fig. 4). Fewer respondents viewed removal of leafroll-diseased vines as cost prohibitive when it was understood that it impacts the economic sustainability of the grape industry (Fig. 3).

Mealybugs. Respondents' perceptions of mealybug incidence were related to their knowledge of disease ecology and willingness to adopt GLD management practices. Specifically, those who reported no mealybugs were less likely to believe there was a clear understanding of mechanisms and management of secondary spread of GLRaV-3. They were also more likely to believe that mealybugs were not a vector, compared with those who reported the presence of either vine or grape mealybugs (Fig. 8). Those who did not believe mealybugs were a vector were less likely to map and remove leafroll-diseased vines or adopt vector management practices (Fig. 4). They were also less likely to adopt virus screening practices (Fig. 4), in either the nursery or production vineyard, and more likely to consider virus screening and vector management as too expensive (Fig. 3).

RBD ecology. Respondents who believed there is a clear understanding of RBD management were more likely to map visual symptoms, remove and replace infected vines, and manage vectors (Fig. 5). When respondents understood that RBD has economic impacts on the industry, adoption of virus screening was greater (Fig. 5), and replacement of infected vines was less likely to be considered cost prohibitive (Fig. 3).

\section{Regional differences}

Regional variations were the only differences that emerged from the demographic comparisons. A higher percentage of respondents in California viewed controlling mealybugs as too expensive $(+25.8 \% ; P=0.023)$ and reported that wineries were less likely to accept grapes from diseased vines, compared with the Pacific Northwest (Fig. 9). Other regional differences were found for RBD (Fig. 9). In the Pacific Northwest, 93.8\% of respondents were prepared to pay less than $\$ 500$ per acre, $18.8 \%$ of which were not prepared to invest in a program at all. In comparison, $28.2 \%$ of California respondents were willing to pay $\$ 500$ to $\$ 1,000$ per acre and $20.5 \%$ more than $\$ 1,000$ per acre. Regional differences were also found in technical knowledge of RBD. A higher percentage of respondents in California considered diseased blocks to be a risk to neighboring blocks and vineyards and believed that the disease impacts the economic sustainability of the industry.

\section{DISCUSSION}

The current study explored economic and technical knowledge factors that influence the adoption of management practices for GLD and RBD among wine grape industry professionals. The data yielded a complex pattern of relationships based on crosssectional analyses, which cannot determine causation but were used as evidence to delineate overarching themes.

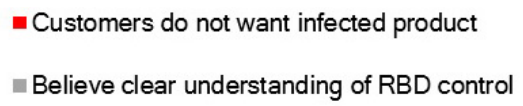

- Practice "too expensive"

nBD impacts economic sustainability

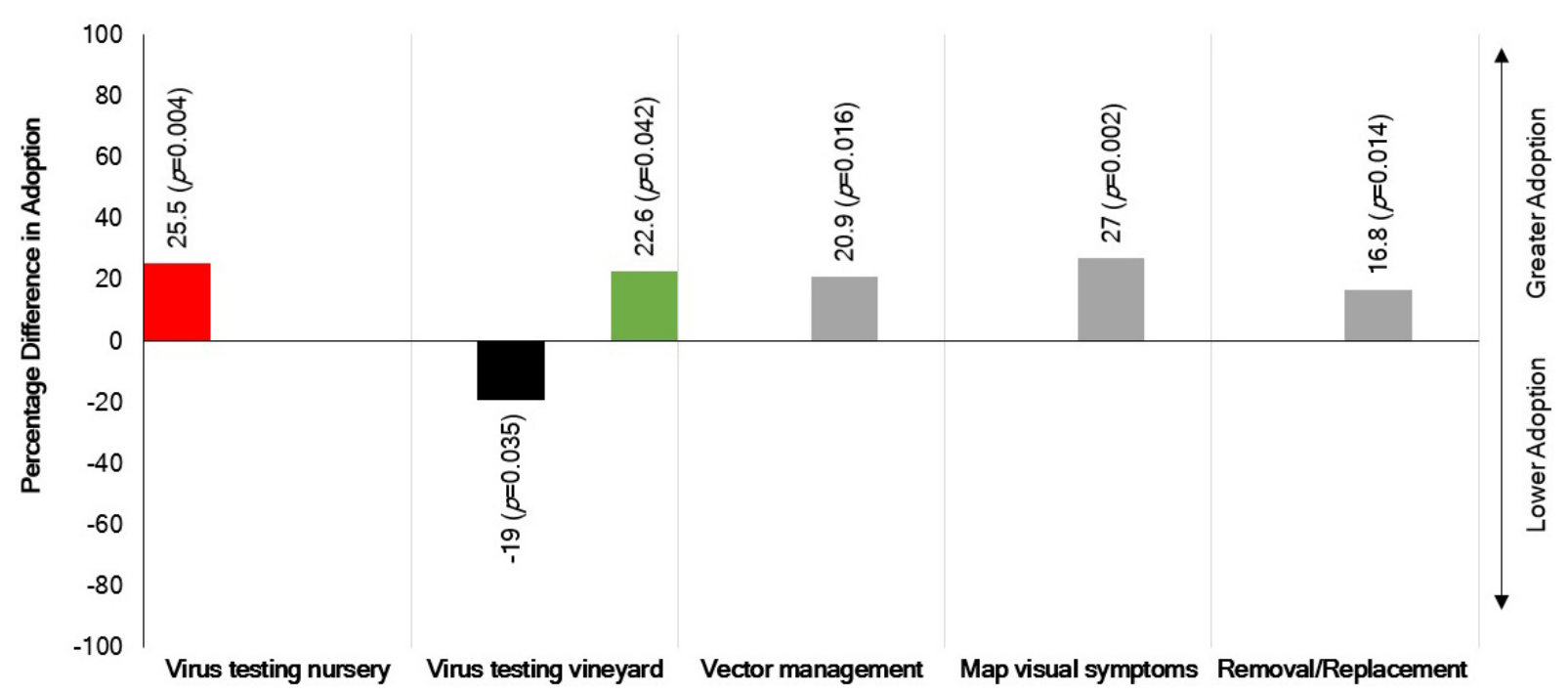

FIGURE 5

Difference in adoption among respondents of grapevine red blotch disease (RBD) management based on perceived costs and reported knowledge of disease ecology. Only significant comparisons displayed. 


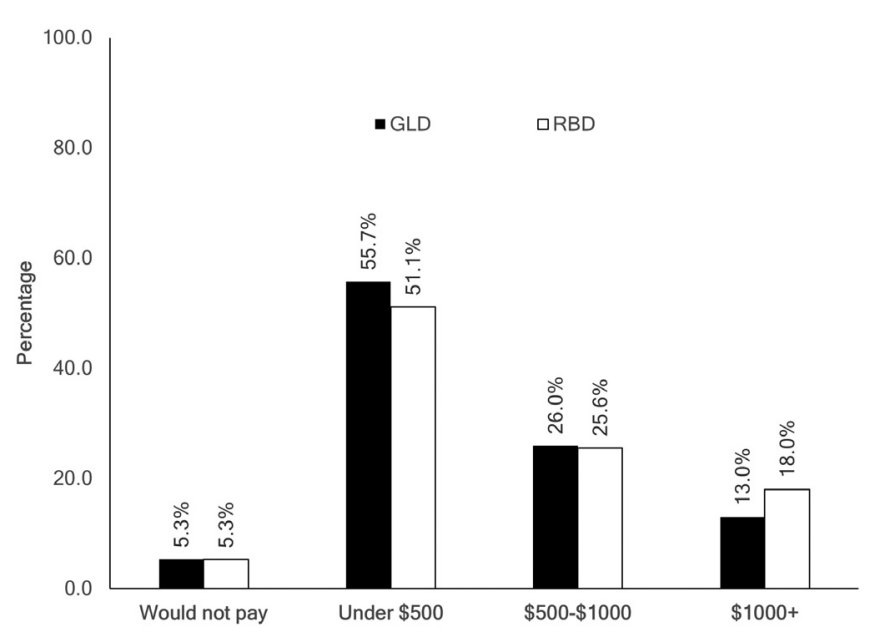

FIGURE 6

Respondents that would pay select cost brackets (per acre) for a control program for grapevine leafroll disease (GLD) $(n=131)$ and grapevine red blotch disease (RBD) $(n=133)$. Note: average combined red and white wine grape price per ton in each region for 2019 and 2020, consecutively (CDFA 2019, 2020; USDA 2021): California: $\$ 708$ and $\$ 678$; Pacific Northwest (Washington): $\$ 1,320$ and $\$ 1,500$.
An important consideration of economic viability is that practices do not just pay for themselves but increase net profits for growers, mainly through increased quantity or quality of products, although increased access and salability are also important aspects (Buurma and van der Velden 2017). The fundamental costs and salability of products were the key economic factors affecting adoption of management practices. Specifically, the costs associated with virus assays and removal/replacement of diseased vines were common barriers to adoption. These costs might be particularly salient due to diagnostic costs, the number of vines that require testing (Arnold et al. 2017), and the presence of asymptomatic vines. The investment of human resources to identify symptomatic vines, collect samples for laboratory assays (Bell et al. 2017), or scout for mealybugs (Daane et al. 2012) was also an important consideration. Higher yields or increased quality and price can compensate for these practices that have high labor input costs (Lefebvre et al. 2015). For example, in California, the cost of mealybug management was an important consideration, likely because of the presence of the invasive species Planococcus ficus (Daane et al. 2012). Producers incur additional costs to provision clean plant material. Although not addressed directly in this study, clean plant material requires a significant public and private investment and the interplay of multiple entities, including clean plant centers, nurseries, producers, and regulatory agencies (Cheon et al. 2020; Fuller et al. 2019). External factors, such as government and industry

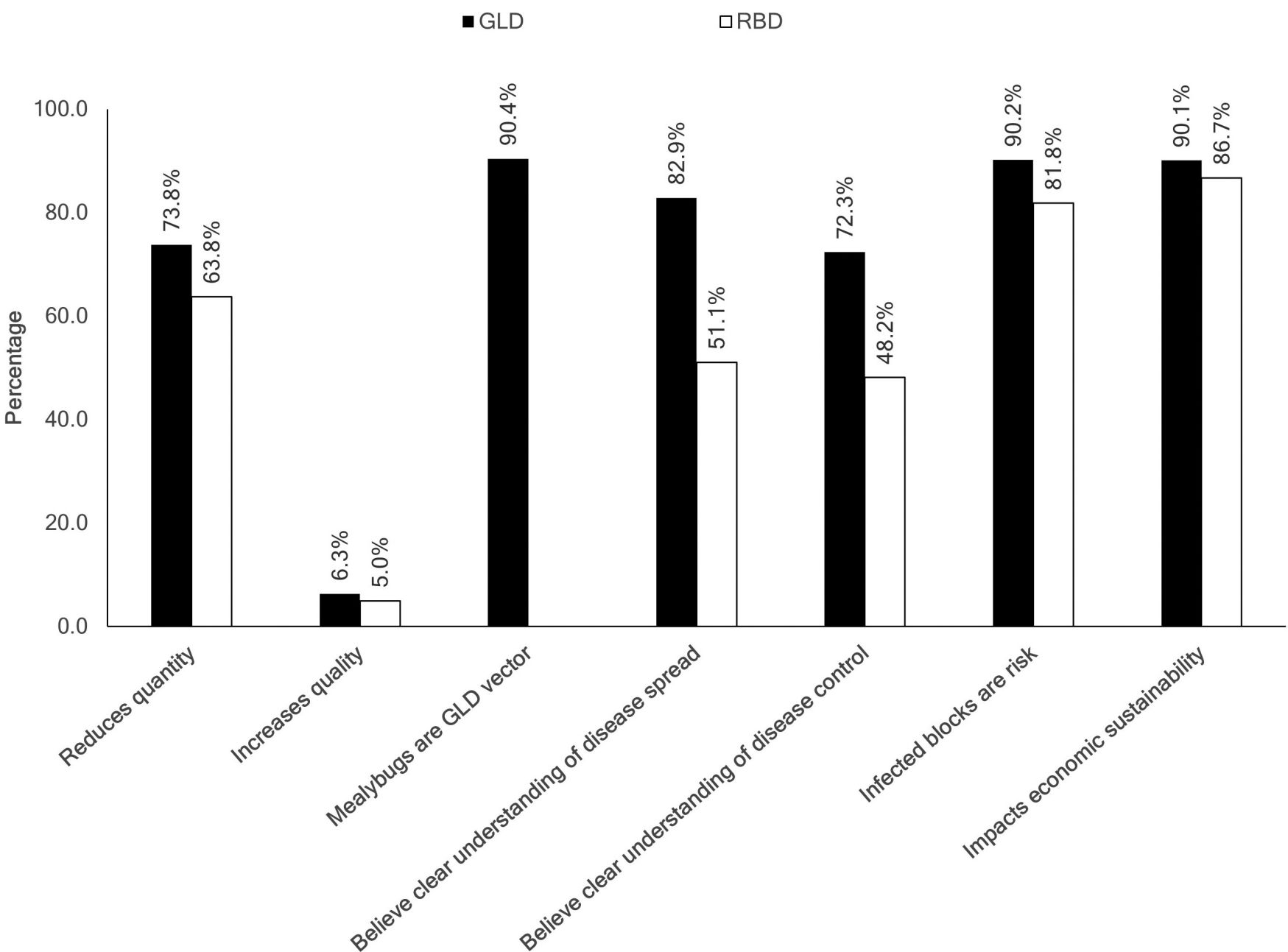

FIGURE 7

Respondents that answered "true" to statements about grapevine leafroll disease (GLD) and grapevine red blotch disease (RBD) $(n=$ 136 to 143 for each statement). 
standards associated with provisioning virus-tested plant material, are currently being explored in complementary interviews with select respondents from this study. The financial burden of adopting all management practices could mean that producers will prioritize certain practices over others; it would be useful to discern how cost perceptions change for the simultaneous adoption of more than one practice.

The ability to sell products is the fundamental economic purpose of agricultural producers. Thus, it is not surprising that salability was a key factor in cost-benefit calculations of disease management, driving investment in control programs, virus testing, and altering the cost perception of diseased vine removal. An overwhelming majority of those who could sell infected products were only prepared to invest limited resources to manage these diseases, whereas those who found it difficult to sell infected products were prepared to invest significantly more. Regional differences in salability between California and the Pacific Northwest also indicate that it could be a driver in regions where there is greater market pressure to reduce disease but a barrier where the majority of customers will accept infected products. However, the effects of supply and demand, as well as contracting agreements, can quickly shift salability, leaving producers without a buyer for fruit from diseased blocks.

Technical knowledge factors and their interaction with economic factors emerged as important considerations. Specifically, it appears that knowledge acquisition drives adoption, and lack of knowledge is a barrier to adoption. For example, growers who understand the secondary spread of GLRaV-3 adopted mapping and removal and replacement of diseased vines, despite high input costs. Furthermore, recognizing that diseased blocks are a risk to surrounding vineyards was associated with a perception of vector management as more economical. Respondents from the Pacific Northwest were less likely to agree that there is a clear understanding of RBD spread and consensus on management, that diseased vines are an infection risk, and that the disease impacts the economic sustainability of the industry. With less documented vine-to-vine transmission of grapevine red blotch virus in these states (Adiputra et al. 2018), this suggests that respondents are controlling spread by screening new plant material and removing infected vines. Coupled with reduced rate of spread, ease of control, and current salability of products, this might explain why RBD was less likely to be viewed as impacting economic sustainability and why there exists greater reluctance to invest in control programs.

One of the most important knowledge factors appeared to be whether respondents understood that mealybugs transmit GLRaV-3 and whether they reported them as present in their vineyards. Although statistical analyses were conducted that considered disparities in group size, these results should be treated with caution as the groups that did not believe mealybugs were vectors $(n=13)$, reported no mealybugs $(n=20)$, and thought monitoring for mealybugs was too expensive $(n=3)$ were small. However, the group that did not know that mealybugs are a vector of GLRaV-3 were less likely to adopt four out of the five

- No Mealybugs $\quad \square \mathrm{VMB} \quad \square \mathrm{GMB}$

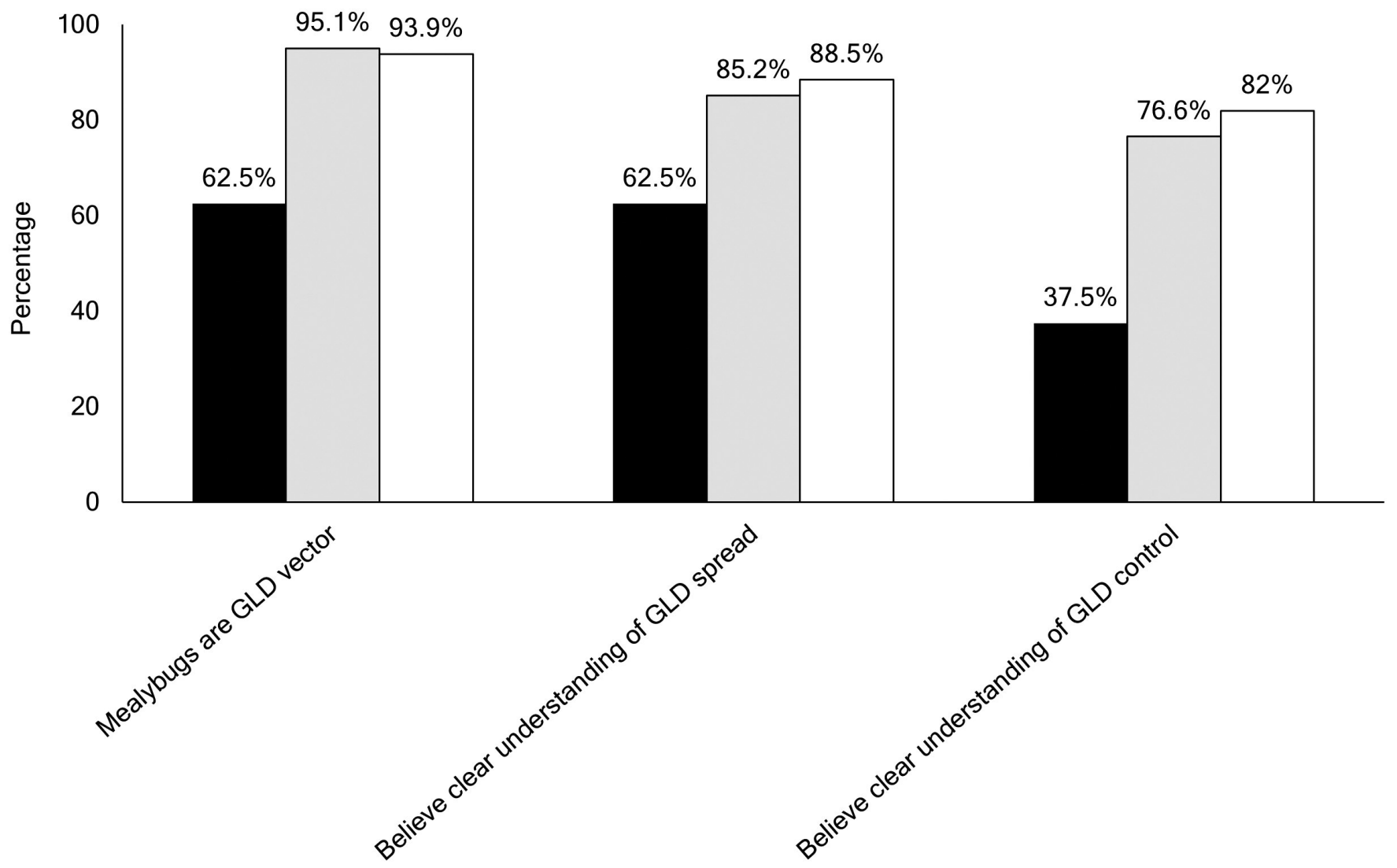

FIGURE 8

For grapevine leafroll disease (GLD), percentage of respondents by self-reported mealybug category: no mealybugs, grape mealybugs (GMB; Pseudococcus maritimus), or vine mealybugs (VMB; Planococcus ficus) who agreed mealybugs are a vector $(P<0.000)$, that there is a clear understanding of disease spread $(P=0.044)$ and mitigation practices $(P=0.002)$. 
practices compared with other respondents, and by large margins ( 29 to $47 \%$ lower). They were also more likely to view virus testing and mealybug control as too expensive. Those reporting no mealybugs in their vineyards were also less likely to have adopted any of the practices. There are two potential explanations. One is that respondents with no mealybugs have little reason to acquire knowledge of disease ecology and management; thus, their understanding is limited. The second is that despite the presence of vectors, these respondents were not adopting practices because they had not acquired knowledge or had misperceptions about the scientific conclusions. The current study cannot distinguish which is the case but reinforces that accurate technical knowledge is an important driver for the adoption of management practices.

The survey did not address the reasons for differences in knowledge acquisition among respondents. Extension activities and tailored technical information can reduce knowledge gaps and drive adoption (Baumgart-Getz 2012; Lui et al. 2018). An encouraging sign is that the level of knowledge appeared high in the current sample, as did overall adoption, especially of the most important practices. This suggests that outreach activities have had considerable success. A more nuanced understanding of how extension can be most effective will enable these adoption rates to be maintained or increased and similar techniques to be applied to other pathogen systems.

A comparison of factors affecting adoption of management practices suggests that they are broadly generalizable across diseases in that they were both influenced by salability, implemen- tation costs, and knowledge acquisition, consistent with other studies (Bechini et al. 2020; Buurma and van der Velden 2017; Kaplan et al. 2016; Lefebvre et al. 2015; Yang and Sharp 2017). However, the two diseases differed at the intersection of technical knowledge and economic considerations. The adoption of all practices for GLD was clearly associated with an understanding of epidemiological factors, whereas for RBD, economic considerations played a stronger role in decision-making. This key difference reflects the disparity between established scientific information on GLRaV-3 transmission biology (Tsai et al. 2008), patterns of spread and vector occurrence (Arnold et al. 2017; Herrbach et al. 2017), and management practices (Bell et al. 2018; MacDonald et al. 2021) compared with more limited vector occurrence and ongoing investigations into the epidemiology of RBD (Cieniewicz et al. 2018; Flasco et al. 2021). The detailed information and experience with GLD allowed us to delve more deeply into perceptions and management, making the differences more apparent. Nevertheless, the strength of the relationship between knowledge of GLD ecology and adoption of management practices highlights that a key to driver for the adoption of RBD management practices will likely lie in acquiring the same level of understanding across multiple regions where it is reported to occur.

The current study identified economic, technical, and regional factors affecting adoption of disease management practices and highlighted the importance of closing knowledge gaps, promoting knowledge acquisition, and developing practices that are

\section{- California $\quad \square$ Pacific Northwest}

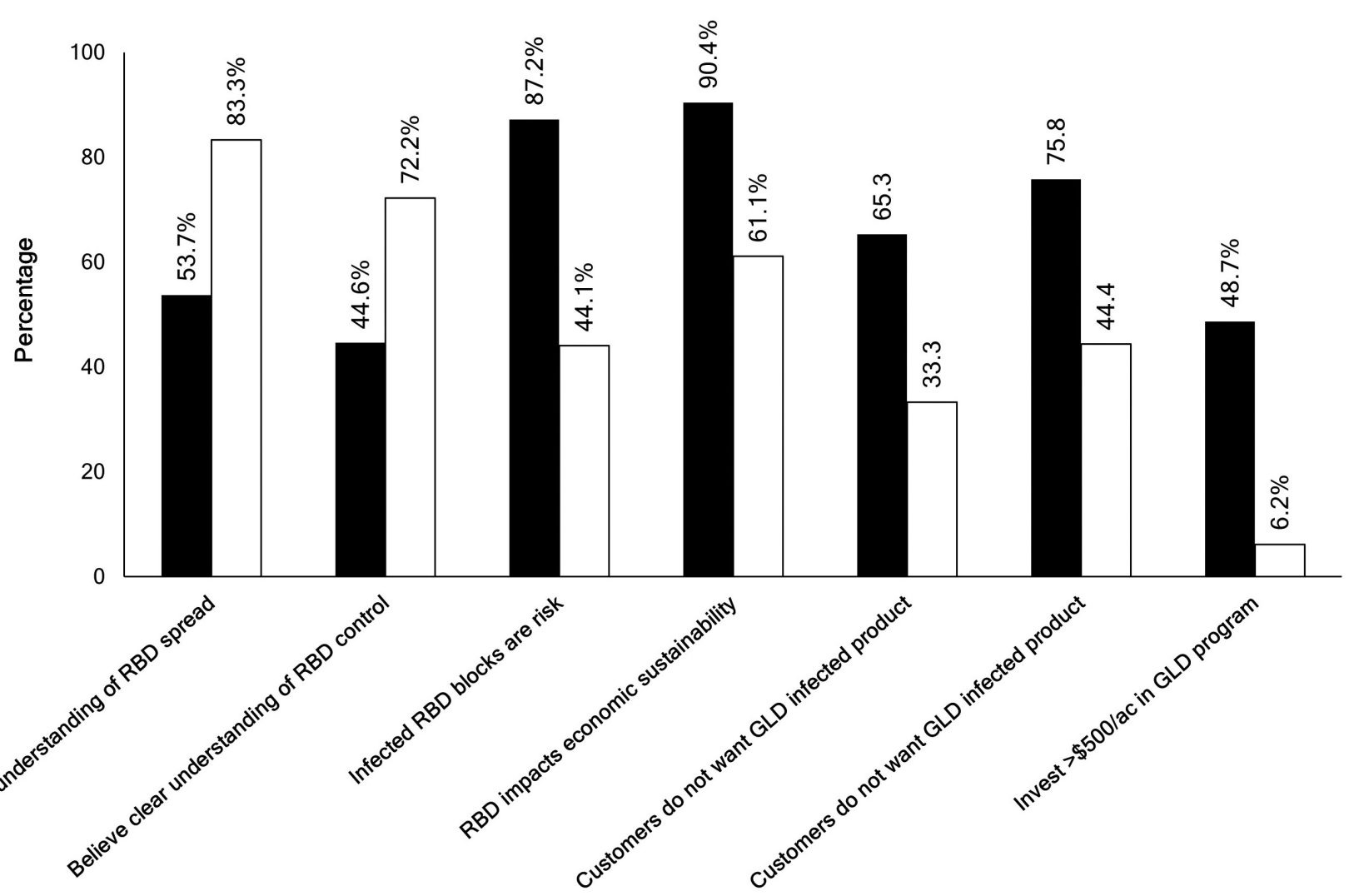

FIGURE 9

Regional differences in responses between California and the Pacific Northwest. Respondents in California found it harder to sell products infected with grapevine leafroll disease (GLD; $P=0.009)$ or grapevine red blotch disease (RBD; $P=0.005)$; believed vineyard blocks with RBD are a risk to neighboring vineyards $(P<0.000)$ and that RBD impacts the economic sustainability of the industry $(P=0.001)$; were willing to invest more than $\$ 500 /$ ac in a management program $(P=0.007)$. Respondents in the Pacific Northwest thought there was a clear understanding of how RBD spreads $(P=0.003)$ and how to control it $(P=0.029)$. 
economical and ensure the salability of agronomic products. The survey did not directly address how to overcome the identified barriers to drivers. Technological advances are one obvious solution to overcome cost barriers, for example, computer algorithms for disease symptom identification (Ghosal et al. 2018) or more convenient assays for viruses (Romero et al. 2019) that would allow for greater flexibility in sample processing.

The survey was limited in that the questions were based on the authors' a priori assumptions; additional economic and technical factors might exist that could not be identified using this survey. Additionally, this survey did not consider social factors that also influence adoption of practices, such as perceptions of the expected outcomes (Bechini et al. 2020), perceived ability to implement practices (Drost et al. 1996; Sterio et al. 2020), diversity of viewpoints, access to training programs, opportunities to experiment (Alwang 2019), and cooperation among producers (Barzman et al. 2015). To investigate social factors and additional technical and economic considerations that influence adoption, semistructured interviews were conducted with a subsample of respondents, and results will be reported subsequently.

\section{LITERATURE CITED}

Adiputra, J., Kesoju, S. R., and Naidu, R. A. 2018. The relative occurrence of Grapevine leafroll-associated virus 3 and grapevine red blotch virus in Washington state vineyards. Plant Dis. 102:2129-2135.

Almeida, R. P. P., Daane, K. M., Bell, V. A., Blaisdell, G. K., Cooper, M. L., Herrbach, E., and Pietersen, G. 2013. Ecology and management of grapevine leafroll disease. Front. Microbiol. 4:1-13.

Alwang, J., Norton, G., and Larochelle, C. 2019. Obstacles to widespread diffusion of IPM in developing countries: Lessons from the field. J. Integr. Pest Manage. 10:1-8.

Arnold, K., Golino, D. A., and McRoberts, N. 2017. A synoptic analysis of the temporal and spatial aspects of grapevine leafroll disease in a historic Napa vineyard and experimental vine blocks. Phytopathology 107: 418-426.

Atallah, S., Gomez, M., Fuchs, M., and Martinson, T. 2012. Economic impact of grapevine leafroll disease on Vitis vinifera cv. Cabernet franc in Finger Lakes vineyards of New York. Am. J. Enol. Vitic. 63:73-79.

Bahder, B. W., Zalom, F. G., Jayanth, M., and Sudarshana, M. R. 2016. Phylogeny of geminivirus coat protein sequences and digital PCR aid in identifying Spissistilus festinus as a vector of grapevine red blotchassociated virus. Phytopathology 106:1223-1230.

Barzman, M., Bàrberi, P., Birch, A. N. E., Boonekamp, P., DachbrodtSaaydeh, S., Graf, B., Hommel, B., Jensen, J. E., Kiss, J., Kudsk, P., Lamichhane, J. R., Messéan, A., Moonen, A-C., Ratnadass, A. Ricci, P. Sarah, J. L., and Sattin, M. 2015. Eight principles of integrated pest management. Agron. Sustain. Dev. 35:1199-1215.

Baumgart-Getz, A., Prokopy, L. S., and Floress, K. 2012. Why farmers adopt best management practice in the United States: A meta-analysis of the adoption literature. J. Environ. Manage. 96:17-25.

Bechini, L., Costamagna, C., Zavattaro, L., Grignani, C., Bijttebier, J., and Ruysschaert, G. 2020. Drivers and barriers to adopt best management practices: Survey among Italian dairy farmers. J. Clean. Prod. 245:118825.

Bell, V. A., Blouin, A. G., Cohen, D., Hedderley, D. I., Oosthuizen, T., Spreeth, N., Lester, P. J., and Pietersen, G. 2017. Visual symptom identification of Grapevine leafroll-associated virus 3 in red berry cultivars supports virus management by roguing. J. Plant. Pathol. 99:477-482.

Bell, V. A., Hedderley, D. I., Pietersen, G., and Lester, P. J. 2018. Vineyardwide control of Grapevine leafroll-associated virus 3 requires an integrated response. J. Plant Pathol. 100:399-408.

Blanco-Ulate, B., Hopfer, H., Figueroa-Balderas, R., Ye, Z., Rivero, R. M., Albacete, A., Pérez-Alfocea, F., Koyama, R., Anderson, M. M., Smith, R. J., Ebeler, S. E., and Cantu, D. 2017. Red blotch disease alters grape berry development and metabolism by interfering with the transcriptional and hormonal regulation of ripening. J. Exp. Bot. 68:1225-1238.

Bowen, P., Bogdanoff, C., Poojari, S., Usher, K., Lowery, T., and UrbezTorres, J. R. 2020. Effects of grapevine red blotch disease on Cabernet franc vine physiology, bud hardiness, and fruit and wine quality. Am. J. Enol. Vitic. 71:308-318.

Buurma, J. S., and Van der Velden, N. J. A. 2017. New approach to integrated pest management research with and for horticulture: A vision from and beyond economics. J. Crop Prot. 97:94-100.
California Department of Food and Agriculture (CDFA). 2019. California errata to the grape crush report crop year 2019. Historical Crush Reports. https://www.nass.usda.gov/Statistics_by_State/California/Publications/ Specialty_and_Other_Releases/Grapes/Crush/Reports/index.php

California Department of Food and Agriculture (CDFA). 2020. California errata to the grape crush report crop year 2020. Historical Crush Reports. https://www.nass.usda.gov/Statistics_by_State/California/Publications/ Specialty_and_Other_Releases/Grapes/Crush/Reports/index.php

Charles, J. G., Froud, K. J., Van den Brink, R., and Allan, D. J. 2009. Mealybugs and the spread of Grapevine leafroll-associated virus 3 (GLRaV-3) in a New Zealand vineyard. Australas. Plant Pathol. 38: 576-583.

Cheon, J. Y., Fenton, M., Gjerdseth, E., Wang, Q., Gao, S., Krovetz, H., Lu, L., Shim, L., Williams, N., and Lybbert, T. 2020. Heterogeneous benefits of virus screening for grapevines in California. Amer. J. Enol. Vit. 71: 231-241.

Cieniewicz, E., Flasco, M., Brunelli, M., Onwumelu, A., Wise, A., and Fuchs, M. 2019. Differential spread of grapevine red blotch virus in California and New York vineyards. Phytobiomes 3:203-211.

Cieniewicz, E., Pethybridge, S. J., Gorn, A., Madden, L. V., McLane, H., Perry, K. L., and Fuchs, M. 2017. Spatiotemporal spread of grapevine red blotch-associated virus in a California vineyard. Virus Res. 241: 156-162.

Cieniewicz, E., Pethybridge, S. J., Loeb, G., Perry, K., and Fuchs, M. 2018. Insights into the ecology of grapevine red blotch virus in a diseased vineyard. Phytopathology 108:94-102.

Daane, K. M., Almeida, R. P. P., Bell, V. A., Walker, J. T. S., Botton, M., Fallahzadeh, M., Mani, M. M., Miano, J. L., Sforza, R., Walton, V. M., et al. 2012. Biology and management of mealybugs in vineyards. Pages 271-308 in: Arthropod Management in Vineyards: Pests, Approaches and Future Directions. N. J. Bostanian, R. Isaacs, and C. Vincent, eds. Springer, Dordrecht, Netherlands.

Drost, D., Long, G., Wilson, D., Miller, B., and Campbell, W. 1996. Barriers to adopting sustainable agricultural practices. J. Ext. 34:6FEA1.

Farrar, J. J., Baur, M. E., and Elliott, S. F. 2016. Adoption of IPM practices in grape, tree fruit, and nut production in the western United States. J. Integr Pest Manage. 7:1-8.

Flasco, M., Hoyle, V., Cieniewicz, E. J., Hoy, B. G., McLane, H. L., Perry, K. L., Loeb, G., Nault, B., Heck, M., and Fuchs, M. 2021. Grapevine red blotch virus is transmitted by the threecornered alfalfa hopper in a circulative, nonpropagative mode with unique attributes. Phytopathology 111:1851-1861.

Fuller, K. B., Alston, J. M., and Golino, D. A. 2019. Economic benefits of virus screening: A case study of grapevine leafroll in the north coast of California. Amer. J. Enol. Vitic. 70:139-146.

Ghosal, S., Blystone, D., Singh, A. K., Ganapathysubramanian, B., Singh, A., and Sarkar, S. 2018. An explainable deep machine vision framework for plant stress phenotyping. Proc. Natl. Acad. Sci. U.S.A. 115:4613-4618.

Herrbach, E., Alliaumme, A., Prator, C. A., Daane, K., Cooper, M. L., and Almeida, R. P. P. 2017. Vector transmission of grapevine leafrollassociated viruses. Pages 483-503 in: Grapevine Viruses: Molecular Biology, Diagnostics and Management. B. Meng, G. P. Martelli, D. A. Golino, and M. Fuchs, eds. Springer, Dordrecht, Netherlands.

Holm, S. 1979. A simple sequential rejective multiple test procedure. Scand J. Stat. 6:65-70

Kaplan, J., Travadon, R., Cooper, M., Hillis, V., Lubell, M., and Baumgartner, K. 2016. Identifying economic hurdles to early adoption of preventative practices: The case of trunk diseases in California winegrape vineyards. Wine Econ. Policy 5:127-141.

Lefebvre, M., Langrell, S. R. H., and Gomez-y-Paloma, S. 2015. Incentives and policies for integrated pest management in Europe: A review. Agron. Sustain. Dev. 35:27-45

Lui, T., Bruins, R. J. F., and Heberling, M. T. 2018. Factors influencing farmers' adoption of best management practices: A review and synthesis. Sustainability 10:432.

MacDonald, S. L., Schartel, T., and Cooper, M. L. 2021. Exploring growersourced data to understand spatiotemporal trends in the occurrence of a vector, Pseudodoccus maritimus (Hemiptera: Pseudococcidae) and improve grapevine leafroll disease management. J. Econ. Entomol. 114:14521461.

Maree, H. J., Almeida, R. P. P., Bester, R., Chooi, K. M., Cohen, D., Dolja, V. V., Fuchs, M. F., Golino, D. A., Jooste, A. E. C., Martelli, G., Naidu, R. A., Rowhani, A., Saldarelli, P., and Burger, J. T. 2013. Grapevine leafroll-associated virus 3. Front. Microbiol. 4:1-21.

Martínez-Lüscher, J., Plank, C. M., Brillante, L., Cooper, M. L., Smith, R., Al-Rwahnih, M., Yu, R., Oberholster, A., Girardello, R., and Kurtural, S. K. 2019. Grapevine red blotch virus may reduce carbon translocation leading to impaired grape berry ripening. J. Agric. Food Chem. 67: 2437-2448. 
Naidu, R., Rowhani, A., Fuchs, M., Golino, D., and Martelli G. P. 2014. Grapevine leafroll: A complex viral disease affecting a high value fruit crop. Plant Dis. 98:1172-1185.

Pietersen, G., Spreeth, N., Oosthuizen, T., Van Rensburg, A., Van Rensburg, M., Lottering, D., Rossouw, N., and Tooth, D. 2013. Control of grapevine leafroll disease spread at a commercial wine estate in South Africa: A case study. Am. J. Enol. Vitic. 64:296-305.

Poojari, S., Boule, J., DeLury, N., Lowery, D. T., Rott, M., Schmidt, A. M., and Urbez-Torres J. R. 2017 Epidemiology and genetic diversity of grapevine leafroll-associated viruses in British Columbia. Plant Dis. 101:2088-2097.

Preto, C. R., Sudarshana, M. R., and Zalom, F. G. 2018. Feeding and reproductive hosts of Spissistilus festinus (Say) (Hemiptera: Membracidae) found in Californian vineyards. J. Econ. Entomol. 111:2531-2535.

Ricketts, K. D., Gomez, M. I., Atallah, S. S., Fuchs, M. F., Martinson, T. E., Battany, M. C., Bettiga, L. J., Cooper, M. L., Verdegaal, P. S., and Smith, R. J. 2015. Reducing the economic impact of grapevine leafroll disease in California: Identifying optimal disease management strategies. Am. J. Enol. Vitic. 66:138-147.

Ricketts, K. D., Gomez, M. I., Fuchs, M. F., Martinson, T. E., Smith, R. J., Cooper, M. L., Moyer, M. M., and Wise, A. 2017. Mitigating the economic impact of grapevine red blotch: Optimizing disease management strategies in US vineyards. Am. J. Enol. Vitic. 68:127-135.

Romero, J. L. R., Carver, G. D., Johnson, P. A., Perry, K. L., and Thompson, J. R. 2019. A rapid, sensitive and inexpensive method for detection of grapevine red blotch virus without tissue extraction using loop-mediated isothermal amplification. Arch. Virol. 164:1453-1457.

Sokolsky, T., Cohen, Y., Zahavi, T., Sapir, G., and Sharon, R. 2013. Potential efficiency of grapevine leafroll disease management strategies using simulation and real spatio-temporal disease infection data. Aust. J. Grape Wine Res. 19:431-438.

Sterio, A. L., Kvakkestad, V., Breland, T. A., and Vatn, A. 2020. Integrated pest management adoption by grain farmers in Norway: A novel index method. Crop Prot. 135:105-201.

Sudarshana, M. R., Perry, K. L., and Fuchs, M. F. 2015. Grapevine red blotchassociated virus, an emerging threat to the grapevine industry. Phytopathology 105:1026-1032.

Tsai C.-W., Chao, J., Fernandez, L., Bosco, D., Daane, K. M., and Almeida R. P. P. 2008. Transmission of Grapevine leafroll-associated virus 3 by the vine mealybug (Planococcus ficus). Phytopathology 98:1093-1098.

United States Department of Agriculture (USDA). 2021. NW noncitrus fruit and nut 2020 summary. https://www.nass.usda.gov/Statistics_by_State/ Washington/Publications/Fruit/2021/FRUIT.pdf

Yang, W., and Sharp, B. 2017. Spatial dependence and determinants of dairy farmers' adoption of best management practices for water protection in New Zealand. Environ. Manage. 59:594-603.

Yepes, L. M., Cieniewicz, E., Krenz, B., McLane, H., Thompson, J. R., Perry, K. L., and Fuchs, M. 2018. Causative role of grapevine red blotch virus in red blotch disease. Phytopathology 108:902-909. 